\title{
Inventory of Green Spaces and Woody Plants in the Urban Landscape in Ariogala
}

\section{Lina Straigyté}

Faculty of Forest science and Ecology, Aleksandras Stulginskis University Kaunas distr.

Lithuania

lina.straigyte@asu.It

\author{
Tadas Vaidelys \\ Faculty of Forest science and Ecology, \\ Aleksandras Stulginskis University \\ Kaunas distr. \\ Lithuania
}

\section{Abstract}

Background and purpose: Regulation of urban greenery design, management and protection was approved in 2008 in Lithuania after the Green Space Law was passed, allowing protection of public green spaces and woody plants. Protection of these resources first requires an inventory, and we have created a digital database that will help in management of urban green spaces.

Materials and methods: An inventory of green spaces and woody plants was conducted in the public urban territory of Ariogala, using GIS technology. A digital cartographic database was created using ArcGis 9.1 software.

Results and conclusions: Most of the woody plants in the survey area are deciduous trees, and the survey re-

\section{INTRODUCTION}

Regulation of urban greenery design, management and protection in Lithuania was approved in 2008 after the Green Space Law was passed [1]. This law regulates monitoring of the condition of urban greenery [2]. The first survey of green space conditions was conducted in Alytus [3] and focused on application of methodology. V. Stravinskienè assessed the condition of green spaces in the city of Kaunas [4]. The Green Space Law requires conducting inventories of green spaces and woody plants. In performing the inventories, we are planning means of woody plant protection, management and design and building a digital database for green space accounting [5]. The aims of greenery inventory are to identify green space land boundaries, to catalogue species and dimensions of trees and shrubs, to evaluate the qualitative condition of woody plants, to develop accounting data for effective management of the green spaces, to provide information about the sults highlighted the major green space management problems. Often, planted trees grow under power lines, and their crowns touch the power cables. Near blocks of flats, trees are often in the wrong place-planted too close to buildings, trees shade windows and their roots heave pavers and penetrate building foundations. According to the inventory, street trees sustain the most damage, most commonly showing injuries on their trunks and roots. Leaves of Aesculus hipocastanum $L$. show massive damage from Cameraria ohridella Deschka \& Dimić, and Tilia cordata Mill. are damaged by Cercospora microsora Sacc. T. cordata is a favourite city tree, but is susceptible to infestation and when damaged appears unsightly, ending its vegetation period very early. The inventory of green spaces also showed that there are sufficient public parks.

Keywords: street trees, GIS, parks, condition, green spaces

environmental condition of the green spaces and to ensure that the size of the green spaces conforms to valid standards [1].

The inventory of green spaces in Lithuanian towns using GIS technology was launched in 2005. An upgraded methodology of forest inventory, which is more appropriate for individual trees, small tree groups and alleys, was used for inventory of green spaces in towns.

This article analyses the results of the green space inventory of the town of Ariogala.

\section{MATERIALS AND METHODS}

\section{Study Area}

The inventory was conducted in Ariogala, which is located in the central part of Lithuania

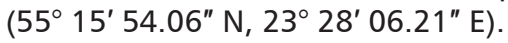


The town of Ariogala covers an area of 480.5 ha, and has a population of 3692 (2001). The inventory encompassed 3436 individuals and 397 groups of woody plants that grow in public areas. Plants on private residential land were not included.

\section{Inventory}

The green space inventory was conducted in JulyAugust 2008, when vegetation is most abundant and can fully reveal the phenological characteristics of the plants, and their condition can accurately be determined. In performing the inventory, we collected the following data: botanical name (species, cultivar) [6]; height (1-metre accuracy); diameter (2-centimetre accuracy); health condition (4-point scale: 1 - good; 2 - fair; 3 - bad; 4 - deadwood).

The condition of woody plants was estimated using the following indicators: pruning intensity, defoliation level, disease and pest damage level, tree trunk (bark) mechanical damage intensity and flagging intensity. Pruning intensity was divided in three groups: 1 - crown reduction to $1 / 3$ of tree head; 2 - crown reduction to $1 / 2-2 / 3$ of tree head; 3 - tree lopping (a trunk with a few branches is left). Tree (shrubs) defoliation was divided in three levels: 1 - healthy or faintly affected (defoliation $0 \%-25 \%$ ); 2 - moderately affected (defoliation 26\%-60\%); 3 - intensely affected (defoliation $>60 \%$ ). Disease intensity, pest abundance and level of damage was grouped: 1 - healthy or faintly damaged by pests and diseases (leaves or needles are healthy or disease or pest damage affects less than $1 / 3$ of their number); 2 - moderately damaged (disease or pest damage between $1 / 3$ and $2 / 3$ of leaves or needles); 3 intensely damaged (disease or pest damage to more than $2 / 3$ of leaves or needles or they are completely destroyed). Tree trunk (bark) mechanical damage intensity groups: 1 - healthy or faintly damaged (no wounds or bark is freshly affected (in the current year) in a small area, less than $\left.30 \mathrm{~cm}^{2}\right) ; 2$ - moderately damaged (there are one or more wounds a few years old in the affected area $\left(50-300 \mathrm{~cm}^{2}\right)$ of bark, which may already be infected by wood-destroying fungi); 3 - intensely damaged (there are one or more wounds a few years old, affecting a large area (more than 300 $\mathrm{cm}^{2}$ ) of bark, trunk of tree is being eroded intensively by wood-destroying fungi).

When plants show different levels of damage in different categories, the lowest score is used to estimate the plant's condition.

Once a plant's condition was estimated, we determined its possible deleterious effects and aesthetic importance [7].
Plants were visually estimated to have a destructive effect whtrees are growing under power cables or in power line protection zones:

- trees and shrubs are close to underground systems (particularly close to drainage lines);

- trees are growing too close to buildings and darkening building windows;

- woody plants isolate small, polluted areas (parking lots of apartment house courtyards and so on) and worsen ventilation;

- surface roots of trees and shrubs destroy hard ground surface (asphalt, precast or tile paving).

When estimating the aesthetic importance of woody plants, their positive and negative impacts on the aesthetics of the environment are determined. Woody plants that improve the environmental aesthetics have the following characteristics: the trees have uniquely shaped or coloured crowns, stems or leaves; the plants have unique characteristics or age; the trees hide objects that are not aesthetically pleasing. Woody plants which have negative impacts on the environmental aesthetics hide artistic buildings or sculptures, cultural or natural heritage objects or valuable landscapes.

After plant condition was estimated and their possible negative impacts and aesthetic importance had been determined, the necessary management measures were planned (pruning, cutting down or removal of plants, rejuvenating shrubs, thinning, cutting deadwood) (Figure 1).

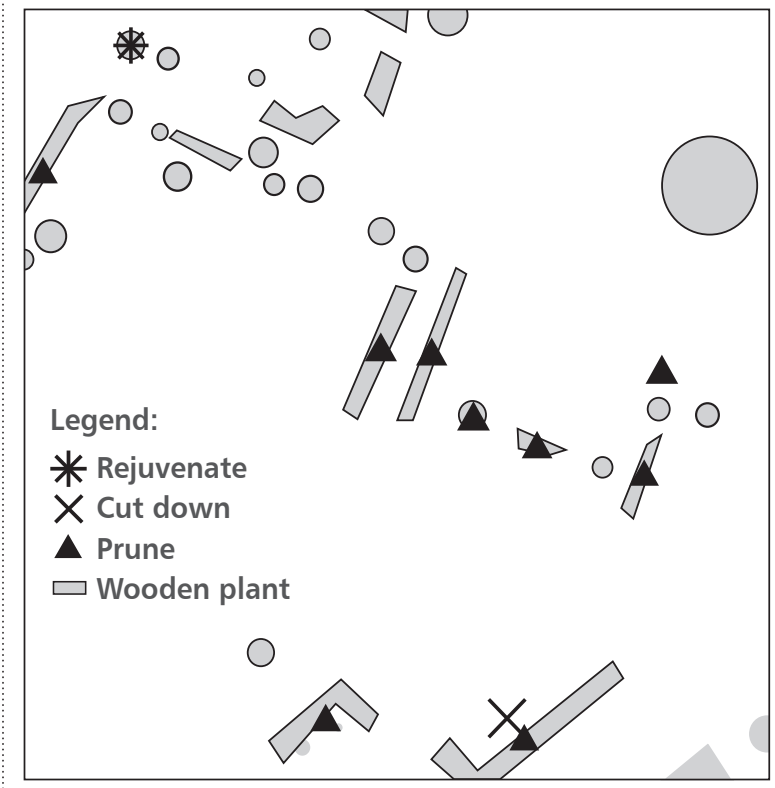

FIGURE 1

Woody plant management map 

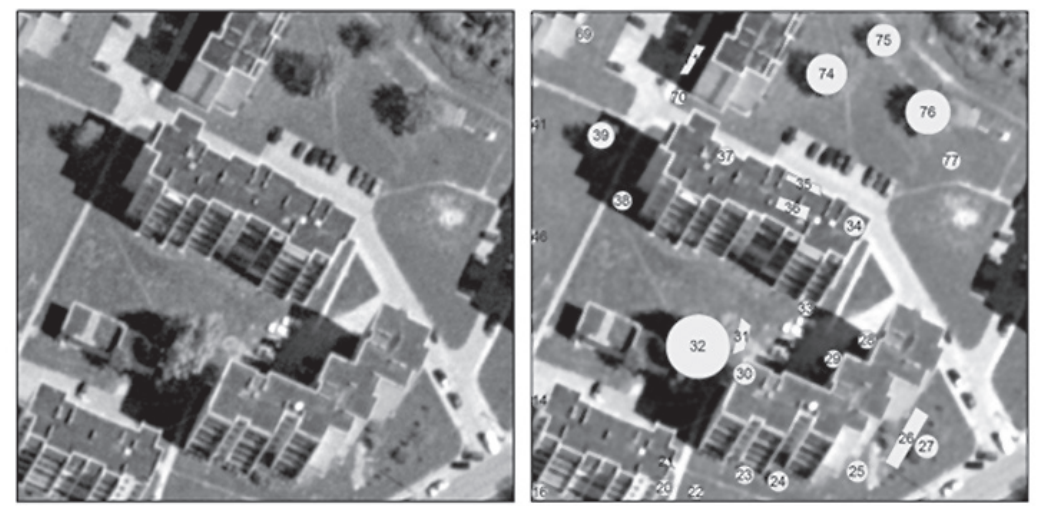

FIGURE 2

Creation of a woody plants layer

\section{Creation of digital databases}

Cartographic material was prepared using ArcGIS 9.1 software. Aerial photographs at 1:2000 scale (in which all green spaces could be seen) were used. After collecting the necessary data for each plant, its location was noted in the photo, and it was given a number. Plant locations, including the canopy, were drawn in a polygon layer. In groups of plants where the canopies of the trees are touching and the location of individual trees could not be distinguished, the location of the entire group was noted. Data were submitted to the Lithuanian coordinate system LKS-94. For plants near tower blocks, location was estimated to scale, because building shadows can hide the plants (Figure 2).

\section{RESULTS}

These results report the woody plant inventory data for the town of Ariogala. Ariogala has 26 taxa of

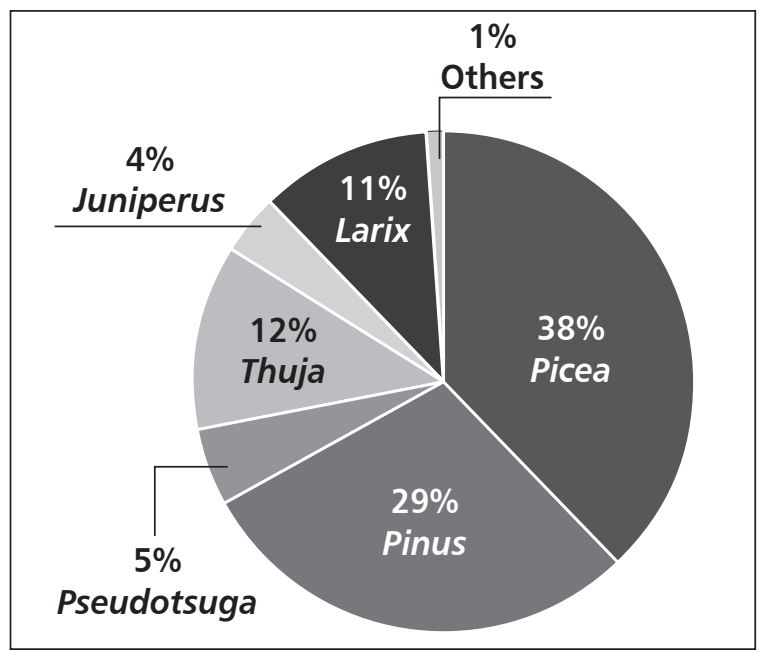

FIGURE 3

Composition of coniferous plants

TABLE 1

Distribution of woody plant taxa in Ariog

\begin{tabular}{|c|c|c|c|c|c|c|c|c|c|c|}
\hline \multirow{2}{*}{ Area } & \multicolumn{4}{|c|}{ Conifers } & \multicolumn{4}{|c|}{ Broadleaves } & Total & Total \\
\hline & genus & species & cultivars & taxa & genus & species & cultivars & taxa & genus & taxa \\
\hline Street & 3 & 5 & 2 & 7 & 15 & 19 & 0 & 19 & 18 & 26 \\
\hline Urban & 9 & 25 & 12 & 37 & 53 & 81 & 13 & 94 & 62 & 131 \\
\hline
\end{tabular}

woody street plants, including 7 conifer taxa and 19 broadleaf taxa. In the nearby town of Raseiniai, which is twice as big as Ariogala, 55 taxa of woody street plants grow [8]. In other public urban green spaces, 37 conifer taxa and 94 broadleaf taxa grow (Table 1).

The most common genus of conifers is Picea. Spruces account for $38 \%$ of the conifer population and pines account for $29 \%$ (Figure 3 ).

Conifers with maximum trunk diameter $(60,52 \mathrm{~cm})$ and tree height $(21,19 \mathrm{~m})$ of conifers are spruces and pines (Table 2).
TABLE 2

Composition of the highest and thickest conifers by genus

\begin{tabular}{|l|c|c|c|}
\hline \multicolumn{1}{|c|}{ Genus } & Taxa & $\mathrm{H}_{\max }(\mathrm{m})$ & $\mathrm{D}_{\max }(\mathrm{cm})$ \\
\hline Taxus L. & 1 & 2.5 & 4 \\
\hline Picea A.Dietr. & 5 & 19 & 52 \\
\hline Abies Mill. & 4 & 10 & 18 \\
\hline Larix Mill. & 4 & 19 & 42 \\
\hline Pseudotsuga Carr. & 3 & 16 & 40 \\
\hline Pinus L. & 6 & 21 & 60 \\
\hline Juniperus L. & 6 & 10 & 10 \\
\hline Chamaecyparis Spach. & 2 & 1.5 & 2 \\
\hline Thuja L. & 6 & 12 & 36 \\
\hline
\end{tabular}


TABLE 3

Composition of the highest and thickest broadleaves by genus

\begin{tabular}{|l|c|c|c|}
\hline \multicolumn{1}{|c|}{ Genus } & Taxa & $\mathrm{H}_{\max }(\mathrm{m})$ & $\mathrm{D}_{\max }(\mathrm{cm})$ \\
\hline Acer L. & 9 & 21 & 68 \\
\hline Aesculus L. & 1 & 16 & 70 \\
\hline Betula L. & 2 & 26 & 56 \\
\hline Fraxinus L. & 3 & 20 & 58 \\
\hline Populus L. & 4 & 30 & 118 \\
\hline Quercus L. & 2 & 23 & 64 \\
\hline Tilia L. & 2 & 20 & 72 \\
\hline
\end{tabular}

The thickest tree in the city is Populus balsamifera L. $(118 \mathrm{~cm})$, and the highest are $P . \times$ canadensis Moench and $P$. nigra 'Italica' (30 m). Table 3 lists the highest and thickest deciduous trees, which mostly grow in town.

The most common species of native deciduous trees are Tilia cordata Mill, Acer platanoides L., Betula pendula Roth, Quercus robur L., Fraxinus excelsior L. In outlying scrubby areas, street woody plant tree stands often included alien species, such as Spiraea chamaedryfolia L. hedges (in 6 places); in town, the alien species Syringa vulgaris L was most common. Of the native shrub species, Prunus padus L., Crataegus monogyna Jacq. were most common.

The largest proportion of the woody plant population is composed of urban plants. In Ariogala, street trees comprise only about $5 \%$ of the city's woody plant population (Figure 4). Conifers comprise even less, only $2.2 \%$. In Chicago, street trees comprise about $10 \%$ [9].

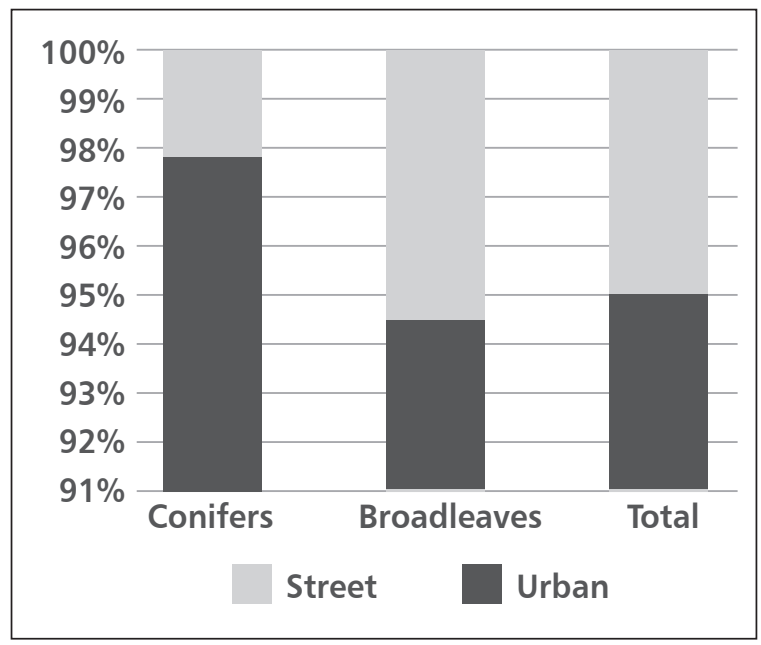

\section{FIGURE 4}

Distribution of conifers and broadleaves in different green spaces

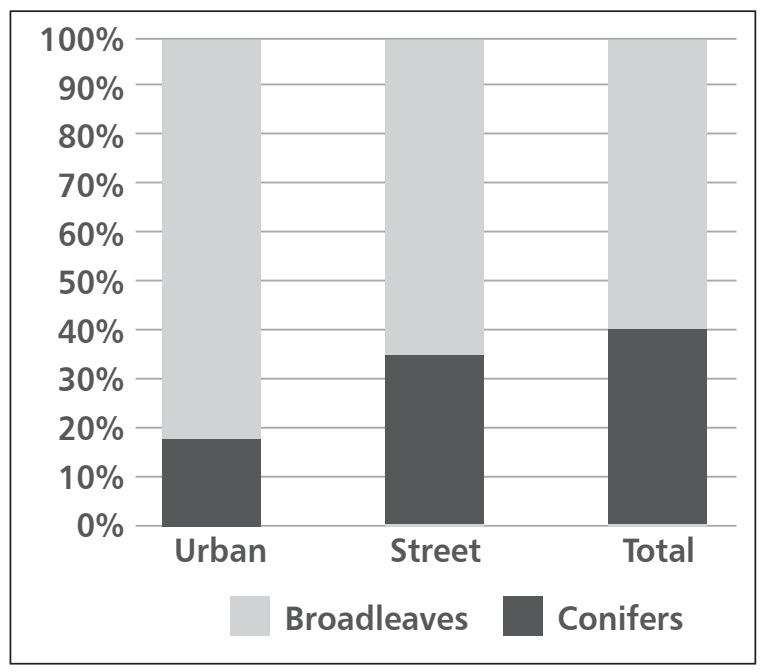

\section{FIGURE 5}

Distribution of urban and street woody plants by division

Broadleaves represent $84 \%$ of all woody plants in green spaces (Figure 5). Conifers are more common in urban green spaces than in street tree stands.

\section{Condition}

Of the estimated 3436 individual woody plants and 397 groups in Ariogala, 88\% are in good or excellent condition (Figure 6).

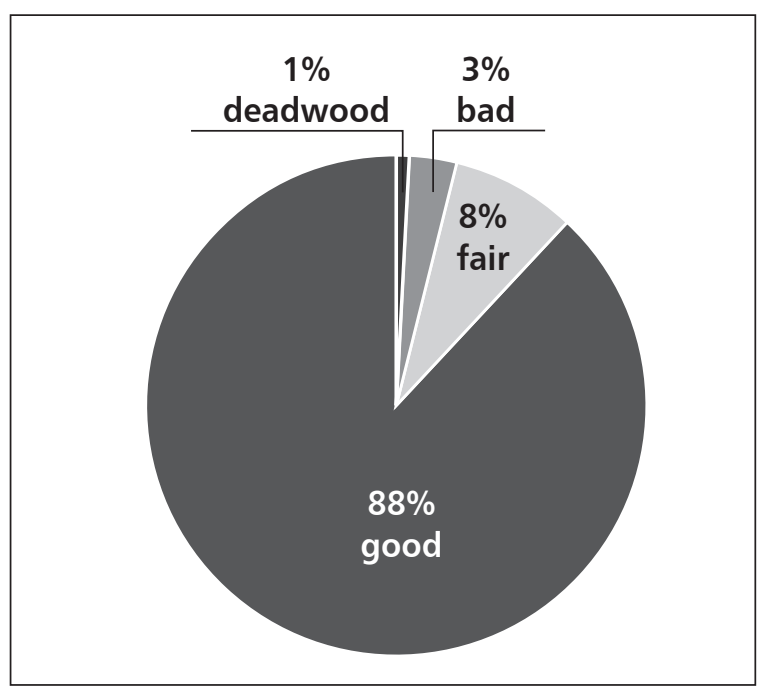

\section{FIGURE 6}

Distribution of woody plants by condition

Trees showing the most damage are street trees. The most common injuries are found on tree stems and roots. Aesculus hipocastanum L. leaves were massively damaged by Cameraria ohridella Deschka 
\& Dimić and those of $T$. cordata Mill. by Cercospora microsora Sacc.

In neighbourhoods of multifamily households, trees are often found in the wrong place: trees planted too close to buildings shade windows, and their roots heave pavers and penetrate foundations.

\section{Green space inventory}

Using aerial photographs, we created a layer that notes all territories and the town green space, in which individual plants and groups of plants growing in the canopy could be hidden (Figure 7).

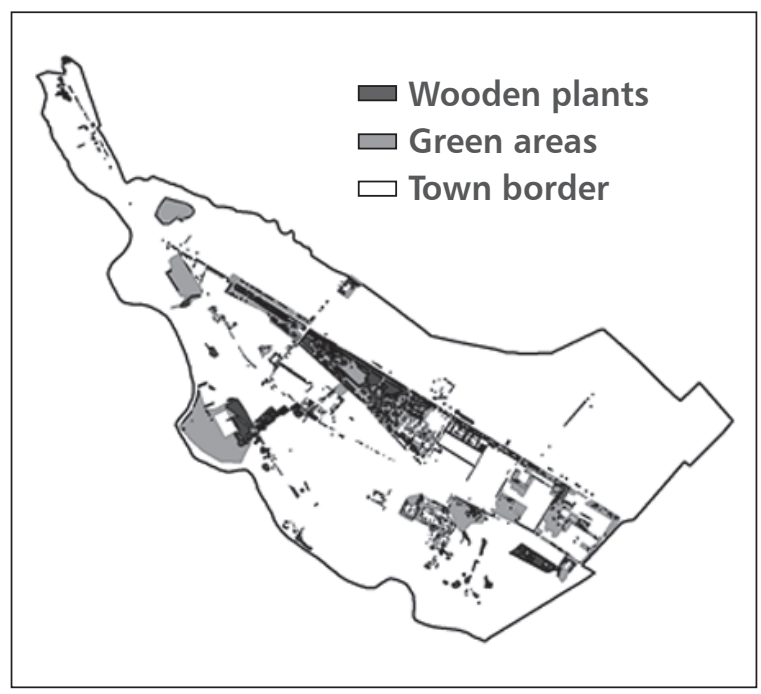

\section{FIGURE 7}

Green space and woody plant cover in Ariogala

Once the digital database inventorying the woody plants was created and the green spaces were mapped, additional information about the canopy cover areas occupied by woody plants was obtained (Table 4).
Once the green spaces were mapped, information about the park green spaces, the cemetery green spaces, the protective green spaces and the integrated green spaces was provided, by area and units (Table 5). Sizes of cemeteries and parks are regulated, while those of other categories of green spaces are not.

\section{DISCUSSION AND CONCLUSIONS}

The main aim of the present study was to collect tree inventory data, including measuring dendrometric parameters and evaluating plant condition. The data collected allow evaluation of the diversity and condition of the dendroflora. Recent tree inventories have revealed which species are most common or rare in Raseiniai [8] and Ariogala [4]. Unfortunately, these methods could not be used to give an accurate estimate of the number of woody plants because woody plants growing in large groups are not counted separately (a group consists of more than 20 woody plants). According to this method of counting woody plants, sums of individual plants and groups are estimated, and therefore, tree inventory data presents only an approximate number of woody plants.

J. Backaitis [10] points out that in some municipalities (Pasvalys), there are specific problems encountered when conducting tree inventories, such as lack of digital databases on city infrastructure. The law and the post-legal acts define that tree inventory work must be conducted by qualified specialists who are able to recognise woody plants and accurately identify their species and cultivar. Unfortunately, the tree inventory is not always performed by forestry professionals, but by individuals who do not know the rare species of trees and shrubs. In this case, inaccurate information about the city's dendroflora is catalogued.

Tree inventory data has highlighted some errors in street tree care and species selection. In the streets of

TABLE 4

Canopy cover area of street and urban woody plants

\begin{tabular}{|c|c|c|c|}
\hline \multicolumn{2}{|c|}{ Urban trees } & \multicolumn{2}{c|}{ Street trees } \\
\hline Canopy cover area (ha) & Site (unit) & Canopy cover area (ha) & Site (unit) \\
\hline 18.2 & 1197 & 0.47 & 68 \\
\hline
\end{tabular}

TABLE 5

The distribution, by area and units, of different categories of green space

\begin{tabular}{|c|c|c|c|c|c|c|c|}
\hline \multicolumn{2}{|c|}{ Integrated } & \multicolumn{2}{c|}{ Protective } & \multicolumn{2}{c|}{ Parks } & \multicolumn{2}{c|}{ Cemetery } \\
\hline Area (ha) & Site (unit) & Area (ha) & Site (unit) & Area (ha) & Site (unit) & Area (ha) & Site (unit) \\
\hline 17 & 62 & 3.7 & 9 & 34.3 & 8 & 5.1 & 2 \\
\hline
\end{tabular}


Ariogala, $80 \%$ [11] of the woody plants are healthy, but the figure is $8 \%$ less in town. Often planted trees grow under power lines, and their crowns start to seek the power cables. Rows of woody plants should instead be planted near streets. The same species or cultivars should be selected for rows of trees. Plant cultivars with narrow and low crowns, and those that need infrequent cutting should be chosen, especially if they grow under power cables. T. cordata is a favourite tree, but this species is susceptible to infestation and appears unappealing when damaged; it also ends its vegetation period very early in the year.

In large cities (Vilnius, Kaunas, Klaipedda), where land has great commercial value, it is common to find trees that have been artificially damaged, probably with the purpose of killing them to create space for installing parking spaces. In smaller towns, where land has no significant commercial value and enough there are sufficient parking spaces for cars, such cases do not often occur.

The green space system was created in order to preserve the landscape's structure, biodiversity and historic value, to maintain its ecological stability and to improve people's living and working conditions $[12,13]$. It offered two types of green spaces: green spaces for general use (parks, town gardens, squares, etc.), and green spaces integrated for various purposes (dwelling, industrial and commercial activities, learning, etc.) [14]. In urban planning divisions green space has already attracted criticism and proposals for classification according to the prevailing greenery [15].

During the tree inventory, the easiest way to distinguish the boundaries of city parks, squares and cemeteries was found. These boundaries are easily seen in aerial photography, often framed with roads, sidewalks and fences. Other green space boundaries cannot visually be distinguished accurately if the area is not fenced. It is extremely difficult to determine even the preliminary green space boundaries in community areas composed of blocks of flats. Due to the absence of a layer showing planted trees during the inventory process, visual determination of the boundaries caused many errors, and the boundaries could not be identified if the planted territories did not comply with the relevant standards.

The minimal proportion of green area for recreational purposes should be $20 \mathrm{~m}^{2}$ per inhabitant [16] in order to improve people's living and working conditions, to maintain the ecological stability of the area and to meet the recreational needs of society. There are $73 \mathrm{~m}^{2}$ of green space per habitant for recreational purposes in Ariogala. The city parks form natural oases in the environment [17], and we recommend that there should be a sufficient quantity of benches. Unfortunately, this survey revealed that there is a lack of benches in the parks.

- Survey results highlighted the major green space management problems. Trees had often been planted under power lines, and their crowns had started to seek the power cables. In blocks of flats, planted trees were often found in the wrong places: trees planted too close to buildings shade windows and their roots heave pavers and penetrate foundations.

- Ariogala contains many recreational green spaces. The area of parks is 5 times bigger than recommended. Recreational parks are evenly distributed throughout the city and are easily reached by inhabitants.

- There are not enough woody plant rows in the streets, and some rows contain too many different species. It is advisable to plant rows with the same plants species at equal planting intervals.

\section{Acknowledgement}

The authors would like to thank Enago (www.enago. com) for the English language review.
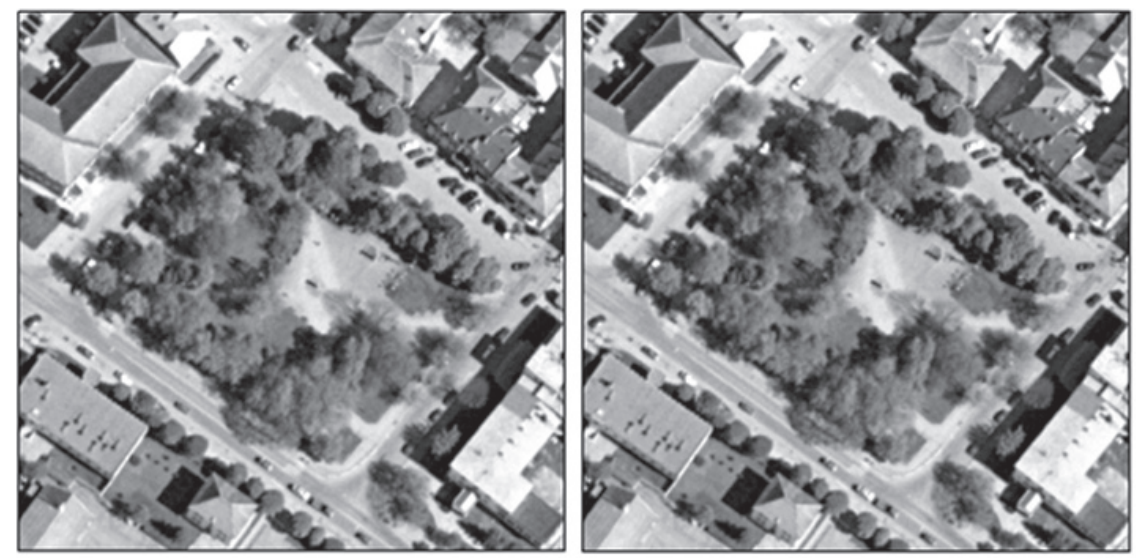

FIGURE 8

Visible square boundaries (left) and non-visible boundaries (right) of housing block sites. 


\section{REFERENCES}

1. LITHUANIAN NEWS 2007 Green spaces Law of Republic of Lithuania, 80-3215 (in lithuanian)

2. LITHUANIAN NEWS 2008 Monitoring program of greenery condition, 10-351 (in lithuanian)

3. ŽEIMAVIČIUS K, SNIEŠKIENÉ $V$, STANKEVIČIENÉ A, VAISVALAVIČIUS R 2011 The methodology of town greenery monitoring program tasks and expected results: case study of Alytus city (in lithuanian). Scripta Horti Botanici Universitatis Vytauti Magni 15: 145-154

4. STRAVINSKIENE் V 2010 Monitoring and assessment of tree health condition in Kaunas city environment. J Environ Eng Landsc 18 (3): 217-225

5. LITHUANIAN NEWS 2008 Rules of green spaces and woody plants inventory and accounting, D1-5 (in lithuanian)

6. NAVASAITIS M 2004 Dendrologija, Vilnius, p 856 (in lithuanian)

7. LITHUANIAN NEWS 2007 Procedure for examination of woody plant condition, D1-673 (in lithuanian)

8. STRAIGYTÉ $L$, ŽALKAUSKAS $R$, PILKAUSKAS $M$, SASNAUSKIENE J 2009 Diversity and Condition of Woody Plants in Raseiniai Green Areas. Rural Development 2009, Proceedings 4 (2): 201-204

9. MCPHERSON E D, NOWAK D, HEISLER G, GRIMMOND S, SOUCH C, GRANT R, ROWNTREE R 1997 Quantifying urban forest structure, function and value: the Chicago Urban Forest Climate Project. Urban Ecosystems 1: 49-61
10. BAČKAITIS J 2011 Decade of green space inventory in Lithuania: results and problems. In: Greenery inventory, design of public spaces, seminar presentation in ASU, 20110401 (in lithuanian)

11. STRAIGYTÉ L 2009 Diversity and condition of woody plants in Ariogala. Proceedings of the 15 International scientific-practice conference "Human and nature safety 2009", Volume 3: 125-128 (in lithuanian)

12. DRINGELIS L 2001 Legal and normative documents to regulate urban green spaces system (in lithuanian). Town planning and architecture 25 (2): 63-70

13. DRINGELIS L 2005 Territory klassification of urban green areas - fundament to plan urban green areas system (in lithuanian). Town planning and architecture 29 (4): 182190

14. JAKOVLEVAS-MATECKIS K 2006 Problems of urban green areas and their social function (in lithuanian). Town planning and architecture 30 (1): 3-14

15. PILKAUSKAS R 2000 Green spaces partition by urban planning. Lithuanian landscape value and the oneness: Kaunas University of Technology, Conference material, pp 64-68 (in lithuanian)

16. LITHUANIAN NEWS 2007 Green spaces Norms for recreational purposes D1-694 (in lithuanian)

17. CHIESURA A 2004 The role of urban parks for the sustainable city. Landscape Urban Plan 68 (1): 129-138 
